\title{
Distribution and Pathogenicity of Colletotrichum Species Associated With Mango Anthracnose in Mexico
}

\author{
J. M. Tovar-Pedraza, ${ }^{1}$ J. A. Mora-Aguilera, ${ }^{2}$ C. Nava-Díaz, ${ }^{2}$ N. B. Lima, ${ }^{3}$ S. J. Michereff, ${ }^{4}$ J. S. Sandoval-Islas, ${ }^{2}$ M. P. S. Câmara, ${ }^{5}$ \\ D. Téliz-Ortiz, ${ }^{2}$ and S. G. Leyva-Mir ${ }^{6, \dagger}$ \\ ${ }^{1}$ Laboratorio de Fitopatología, Coordinación Culiacán, Centro de Investigación en Alimentación y Desarrollo, Culiacán, 80110 \\ Sinaloa, Mexico \\ ${ }^{2}$ Fitopatología, Campus Montecillo, Colegio de Postgraduados, Texcoco, 56230 Estado de México, Mexico \\ ${ }^{3}$ CONICET-Instituto de Patología Vegetal, CIAP-INTA, X5020ICA Córdoba, Argentina \\ ${ }^{4}$ Centro de Ciências Agrárias e da Biodiversidade, Universidade Federal do Cariri, Crato, 63130-025 Ceará, Brazil \\ ${ }^{5}$ Departamento de Agronomia, Universidade Federal Rural de Pernambuco, Recife, 52171-900 Pernambuco, Brazil \\ ${ }^{6}$ Departamento de Parasitología Agrícola, Universidad Autónoma Chapingo, Texcoco, 56230 Estado de México, Mexico
}

\begin{abstract}
Mango anthracnose, caused by Colletotrichum spp., is the most significant disease of mango (Mangifera indica L.) in almost all production areas around the world. In Mexico, mango anthracnose has only been attributed to $C$. asianum and $C$. gloeosporioides. The aims of this study were to identify the Colletotrichum species associated with mango anthracnose symptoms in Mexico by phylogenetic inference using the ApMat marker, to determine the distribution of these species, and to test their pathogenicity and virulence on mango fruits. Surveys were carried out from 2010 to 2012 in 59 commercial orchards in the major mango growing states of Mexico, and a total of 118 isolates were obtained from leaves, twigs, and fruits with typical anthracnose symptoms. All isolates were tentatively identified in the $C$. gloeosporioides species complex

C. asianum, C. fructicola, C. siamense, and C. tropicale were associated with symptoms of mango anthracnose. In this study, C. alienum, C. fructicola, $C$. siamense, and $C$. tropicale are reported for the first time in association with mango tissues in Mexico. This study represents the first report of $C$. alienum causing mango anthracnose worldwide. The distribution of Colletotrichum species varied among the mango growing states from Mexico. Chiapas was the only state in which all five species were found. Pathogenicity tests on mango fruit cultivar Manila showed that all Colletotrichum species from this study could induce anthracnose lesions. However, differences in virulence were evident among species. $C$. siamense and $C$. asianum were the most virulent, whereas $C$. alienum and $C$. fructicola were considered the least virulent species.
\end{abstract} based on morphological and cultural characteristics. The Bayesian inference phylogenetic tree generated with Apn2/MAT intergenic spacer sequences of 59 isolates (one per orchard) revealed that C. alienum,
Keywords: Mangifera indica, morphology, phylogeny, pathogenicity, Colletotrichum
The mango (Mangifera indica L.) is one of the five most economically important fruit crops worldwide, with production occurring in most countries in the tropics and subtropics (Mukherjee and Litz 2009; Paull and Duarte 2011). During the period from 2010 to 2016, Mexico was the fifth largest producer and the largest exporter of mangos worldwide (Food and Agriculture Organization of the United Nations 2017). In Mexico, mango production is distributed in 23 states; however, more than $97 \%$ of the production is concentrated in 10 states (Guerrero, Nayarit, Chiapas, Oaxaca, Sinaloa, Michoacán, Veracruz, Jalisco, Colima, and Campeche) (Servicio de Informacion Agroalimentaria y Pesquera 2017).

Anthracnose, caused by Colletotrichum spp., is the most important disease of mango in almost all production areas, because it attacks leaves, twigs, flowering panicles, and fruits (Arauz 2000; Paull and Duarte 2011; Ploetz 2003; Ploetz and Freeman 2009). Yields are drastically reduced when the inflorescence is attacked. Disease occurs as quiescent infections on immature fruit, but the damage is more economically significant in postharvest fruits (Prusky et al.

${ }^{\dagger}$ Corresponding author: S. G. Leyva-Mir; 1santos@correo.chapingo.mx

Funding: This study was financially supported by SAGARPA-CONACYT (project 48595) and the Colegio de Postgraduados (project 167304). M. P. S. Câmara and S. J. Michereff were supported by research fellowships from the Conselho Nacional de Desenvolvimento Científico e Tecnológico (CNPq) in Brazil.

The author(s) declare no conflict of interest.

Accepted for publication 26 July 2019.

C 2020 The American Phytopathological Society
2009). The incidence of mango anthracnose can reach almost $100 \%$ in fruit produced in areas with high humidity during the flowering period, particularly in poorly managed orchards (Arauz 2000; Ploetz and Freeman 2009).

Anthracnose symptoms in mango orchards may be observed on leaves, twigs, panicles, and fruits. On leaves, lesions are irregular, necrotic, and often surrounded by chlorotic haloes. Lesions may coalesce and form large necrotic areas, especially along the leaf margins. Under favorable conditions, salmon to orange fruiting bodies (acervuli) of the pathogen are formed on the lesions. On twigs, symptoms begin as small, enlarged oval and necrotic lesions that expand and coalesce. During severe infections, the fungus can invade twigs and cause dieback. Small, circular dark lesions also develop on pedicels and peduncles. On panicles, the fungus induces blossom blight and can affect both inflorescence stalk and individual flowers. Fruits may be infected at any stage of their development. Infection on young fruits is often observed as mummification. Infections on larger fruits usually remain latent until the fruit ripens, and it appears as black, irregular, and sunken lesions (Arauz 2000; Ploetz 2003; Ploetz and Freeman 2009; Prakash 2004; Prusky et al. 2009).

Accurate identification of the plant pathogen species is critical to understand the epidemiology of mango anthracnose and develop effective control measures (Cai et al. 2009). Species circumscription and identification of Colletotrichum species has historically been based on host range, symptoms of infection on particular hosts, and a suite of morphological characters (Hyde et al. 2009a, b). However, the use of these conventional taxonomic characters in Colletotrichum species has failed to support the development of a robust species concept because of their plasticity (Cannon et al. 2012; Damm et al. 2012a, b; Hyde et al. 2009a, b; Rojas et al. 2010). According to Marin-Felix et al. (2017) and Damm et al. (2019), there are 14 Colletotrichum species complexes and 15 accepted singleton 
species. All of the complexes can be distinguished from each other by using internal transcribed spacer (ITS) sequence data alone, whereas the species-within-species complex can be resolved by sequence differences in additional genes.

Currently, there are at least 12 Colletotrichum species that have been previously associated with mango tissues worldwide. These species belong to the gloeosporioides $(C$. asianum Prihastuti, Cai \& Hyde; C. fructicola Prihastuti, Cai \& Hyde; C. gloeosporioides Penz. \& Sacc.; C. theobromicola Delacr.; C. siamense Phoulivong, Cai \& Hyde; C. tropicale Rojas, Rehner \& Samuels; C. queenslandicum Weir \& Johnst.; and C. grossum Diao, Zhang, Cai \& Liu), boninense (C. karstii Yang, Liu, Hyde \& Cai), and acutatum (C. fioriniae Shivas \& Tan; C. simmondsii Shivas \& Tan; and C. scovillei Damm, Cannon \& Crous) species complexes, as well as one singleton species as C. cliviicola Damm \& Crous (Jayawardena et al. 2016; Lima et al. 2013; Manzano León et al. 2018; Marin-Felix et al. 2017; Mo et al. 2018; Pardo-De la Hoz et al. 2016; Qin et al. 2019; Sharma et al. 2013; Shivas et al. 2016; Vieira et al. 2014).

In previous studies, the taxonomy of Colletotrichum species associated with mango was identified by phylogenetic multilocus analyses (ACT, TUB2, CAL, CHS, GAPDH, ITS) in conjunction with recognizable phenotypic characters (Cai et al. 2009; Damm et al. 2012a, b; James et al. 2014; Lima et al. 2013; Phoulivong et al. 2010; Udayanga et al. 2013; Weir et al. 2012). However, studies involving Colletotrichum isolates associated with several tropical hosts, including mango, demonstrated that the ApMat marker provided better phylogenetic information compared with other loci used and can resolve species within the $C$. gloeosporioides complex (Doyle et al. 2013; Pardo-De la Hoz et al. 2016; Rojas et al. 2010; Sharma et al. 2013, 2015, 2017; Silva et al. 2012; Vieira et al. 2014).

Until 2014, C. gloeosporioides was identified as the only species associated with mango anthracnose in Mexico (Gutiérrez-Alonso et al. 2001; Rojas-Martínez et al. 2008). In 2014, C. asianum was also identified from mango fruit from Mexico based on multilocus phylogenetic analysis (Honger et al. 2014). The aims of this study were to identify the Colletotrichum species associated with mango anthracnose in Mexico based on phylogenetic analysis using Apn2/MAT intergenic spacer sequence data, to determine the distribution of these species, and to test their pathogenicity and virulence on mango fruits.

\section{Materials and Methods}

Sampling and fungal isolation. Mango leaves, twigs, and fruits with typical anthracnose symptoms (Fig. 1) were collected during several surveys carried out from 2010 to 2012 in various mango cultivars in 59 commercial orchards in the major mango growing states of Mexico (Table 1). Fungal isolates were obtained from infected tissues without visible sporulation using the procedure described by Cai et al. (2009) and Prihastuti et al. (2009). Pure cultures were established from single spores for isolates identified as Colletotrichum species based on morphological characteristics. For samples of symptomatic tissues with reproductive structures (acervuli) on lesions, monoconidial cultures were obtained following the technique of Goh (1999).

Representative cultures of each isolate were deposited in the Culture Collection of Phytopathogenic Fungi of the Department of Agricultural Parasitology at the Chapingo Autonomous University (Texcoco, Estado de México, Mexico). Cultures were maintained as spore suspensions and mycelial plugs in $15 \%$ glycerol at $-80^{\circ} \mathrm{C}$.

Morphology and cultural characteristics. Macroscopic and microscopic characteristics were examined for 118 Colletotrichum isolates. All isolates were subcultured onto potato dextrose agar (PDA) from conidia suspensions stored at $-80^{\circ} \mathrm{C}$. To determine the growth rate of each isolate, mycelial plugs ( $5 \mathrm{~mm}$ in diameter) were taken from 5-day-old cultures and placed onto PDA and malt extract agar (MEA; Difco, Bordeaux, France). The plates were incubated at $25^{\circ} \mathrm{C}$ in darkness. Colony diameters of a three-replicate culture of each isolate were recorded at 24-h intervals over 6 days. Growth rate was calculated as the 6-day average of mean daily growth (in millimeters per day). After 6 days, colony growth characteristics, including surface and reverse colony appearance on each type of agar, were recorded. The experiment was conducted twice.
To study the conidial morphology, conidia per isolate were harvested from actively growing colonies, mounted in $100 \%$ lactic acid, and examined for size and shape at $100 \times$ magnification using a compound microscope (BX41; Olympus, Tokyo, Japan) equipped with differentialinterference-contrast optics. Measurements of 50 conidia were made with Motic Image Plus version 5.0 (Motic Group Co., Jiangsu, China).

DNA extraction, PCR amplification, and sequencing. Aerial mycelium from 6-day-old culture was scraped directly from the medium using a sterile spatula and was placed in 2-ml microtubes. Genomic DNA was extracted from 59 isolates (one isolate per orchard) using the hexacetyltrimethylammonium bromide method described by Doyle and Doyle (1990). DNA concentrations were quantified using a NanoDrop Lite Spectrophotometer (Thermo Fisher Scientific, Madison, WI) and the samples were diluted to $50 \mathrm{ng}^{\mathrm{-1}} \mathrm{l}^{-1}$ for PCR reaction.

PCR amplification of the intergenic spacer between the $3^{\prime}$ end of the DNA-lyase and the mating type locus Mat1-2 (Apn2/Mat-IGS) of the Apn2 and MAT1-2-1 (ApMat marker) was carried out with cycling parameters and primers specified by Doyle et al. (2013). PCR amplifications were conducted in a Bio-Rad C1000 thermocycler (Bio-Rad Laboratories, Hercules, CA). The PCR products were separated by electrophoresis in $1 \%$ agarose gel stained with ethidium bromide and viewed under ultraviolet light. The amplified PCR products were purified using the QIAquick PCR Purification Kit (Qiagen, Valencia, CA) and sequenced by Macrogen Inc. (Seoul, Korea) in both directions with the same primers that were used for the PCR reactions.

Phylogenetic analysis. The quality of the nucleotide sequences and the contig assembly was assessed using the Staden Package (Staden et al. 1998). Multiple sequence alignments of each gene used ClustalW as implemented in MEGA 7 (Kumar et al. 2016) and were manually adjusted to allow maximum sequence similarity. Bayesian phylogenetic estimates were inferred with MrBayes 3.2.6 (Ronquist et al. 2012) implemented on the CIPRES cluster (https://www.phylo.org/portal2/home.action) using the best-fit models of nucleotide substitution selected according to AICc by MrModeltest 2.3 (Nylander 2004). Four parallel runs were conducted with one cold and three heated Markov chain Monte Carlo search chains per run for $5 \times 10^{6}$ generations, sampling every 1,000 generations. Posterior probabilities were calculated after discarding the first $25 \%$ of generations as burn-in. Phylogenetic trees were viewed with TreeView (Page 1996). Sequences generated in this study were deposited in GenBank (Table 1). Alignments and tree files are available in TreeBASE (study no. 23366).

Pathogenicity and virulence on detached fruits. Pathogenicity tests were carried out on detached fruits of mango (cultivar Manila) at the first color break stage of ripening. Mango fruits were thoroughly washed under running water, surface disinfested in $1 \%$ sodium hypochlorite solution for 2 min followed by immersion in $70 \%$ ethanol for $2 \mathrm{~min}$, rinsed two times in sterile distilled water, and dried in a laminar flow hood. The fruits were inoculated using the colonized agar plug method because some isolates had no satisfactory sporulation on the culture medium. Fruits were wounded in two allocated areas with a sterile toothpick ( $3 \mathrm{~mm}$ in depth). A mycelial plug ( $5 \mathrm{~mm}$ in diameter) removed from the margin of a 6-dayold PDA culture was placed onto the fruit surface on each wound. A noncolonized agar plug was placed on the wounds of 10 fruits used as the control. The fruits were incubated at $25^{\circ} \mathrm{C}$ in the dark on plastic trays lined with two layers of paper towel moistened with sterile distilled water and enclosed in a plastic bag. Six days after inoculation, the virulence of each isolate was assessed by measuring lesion diameter. Each isolate was inoculated on three fruits and the experiment was repeated twice. Differences in virulence caused by Colletotrichum species were determined by one-way analysis of variance, and mean values were compared by the least significant difference test at the 5\% significance level using SAS version 9.1 software.

\section{Results}

Fungal isolates. A total of 118 Colletotrichum isolates were obtained from symptomatic mango tissues (110 leaves, five fruits, and three twigs) collected from 59 orchards distributed in the states 
of Chiapas $(n=11)$, Sinaloa $(n=9)$, Nayarit $(n=9)$, Veracruz $(n=9)$, Michoacán $(n=6)$, Oaxaca $(n=6)$, Colima $(n=5)$, and Guerrero $(n=4)$ in Mexico (Table 1).

Morphology and cultural characteristics. In PDA media, colonies generally showed dense, white to grayish growth (Fig. 2). The mycelium growth rate varied from 8.3 to $11.6 \mathrm{~mm} \mathrm{day}^{-1}$ (average $=$ $10.2 \mathrm{~mm} \mathrm{day}^{-1}$ ). In MEA media, the colonies exhibited a growth rate that ranged between 10.6 and $15.0 \mathrm{~mm} \mathrm{day}^{-1}$ (average $=$ $13.7 \mathrm{~mm} \mathrm{day}^{-1}$ ), and they also exhibited greater variation in color from white to gray and beige. Conidia were hyaline, unicellular, and cylindrical $(12.5$ to $18.4 \times 3.5$ to $5.4 \mu \mathrm{m})$, with rounded extremes and inconspicuous hilum (Fig. 2).

All 118 isolates obtained from mango were tentatively identified in the C. gloeosporioides species complex based on morphological and cultural features. However, none of the morphological and cultural features tested allowed discrimination between the species belonging to the $C$. gloeosporioides complex.

Phylogenetic analysis. A total of 59 isolates were characterized for phylogenetic analysis of Apn2/MAT intergenic spacer sequences. The phylogeny provided sufficient information to distinguish five
Colletotrichum species associated with symptoms of mango anthracnose in Mexico. All 59 isolates were nested within the Musae clade of the $C$. gloeosporioides complex with a high level of support with the Bayesian posterior probability values. The five clades corresponded to previously described species: $C$. alienum, C. asianum, C. fructicola, C. siamense, and C. tropicale. Thirty-three isolates were identified as $C$. siamense. Nineteen isolates were identified as $C$. asianum. Four isolates clustered with the type strain of $C$. tropicale. Two isolates were identified as $C$. alienum. Finally, only one isolate clustered with C. fructicola (Fig. 3).

Distribution of Colletotrichum species. The distribution of Colletotrichum species varied among the mango growing states from Mexico (Fig. 4). Chiapas was the only state in which all five species were found. $C$. siamense was found in all mango growing states, and all isolates from Guerrero belonged to this species. C. asianum was found in all sites, except in Guerrero and Oaxaca. C. tropicale was recorded only in the isolates from Sinaloa, Veracruz, and Chiapas. C. alienum was only isolated in samples from Chiapas and Oaxaca, whereas C. fructicola was identified only in Chiapas.
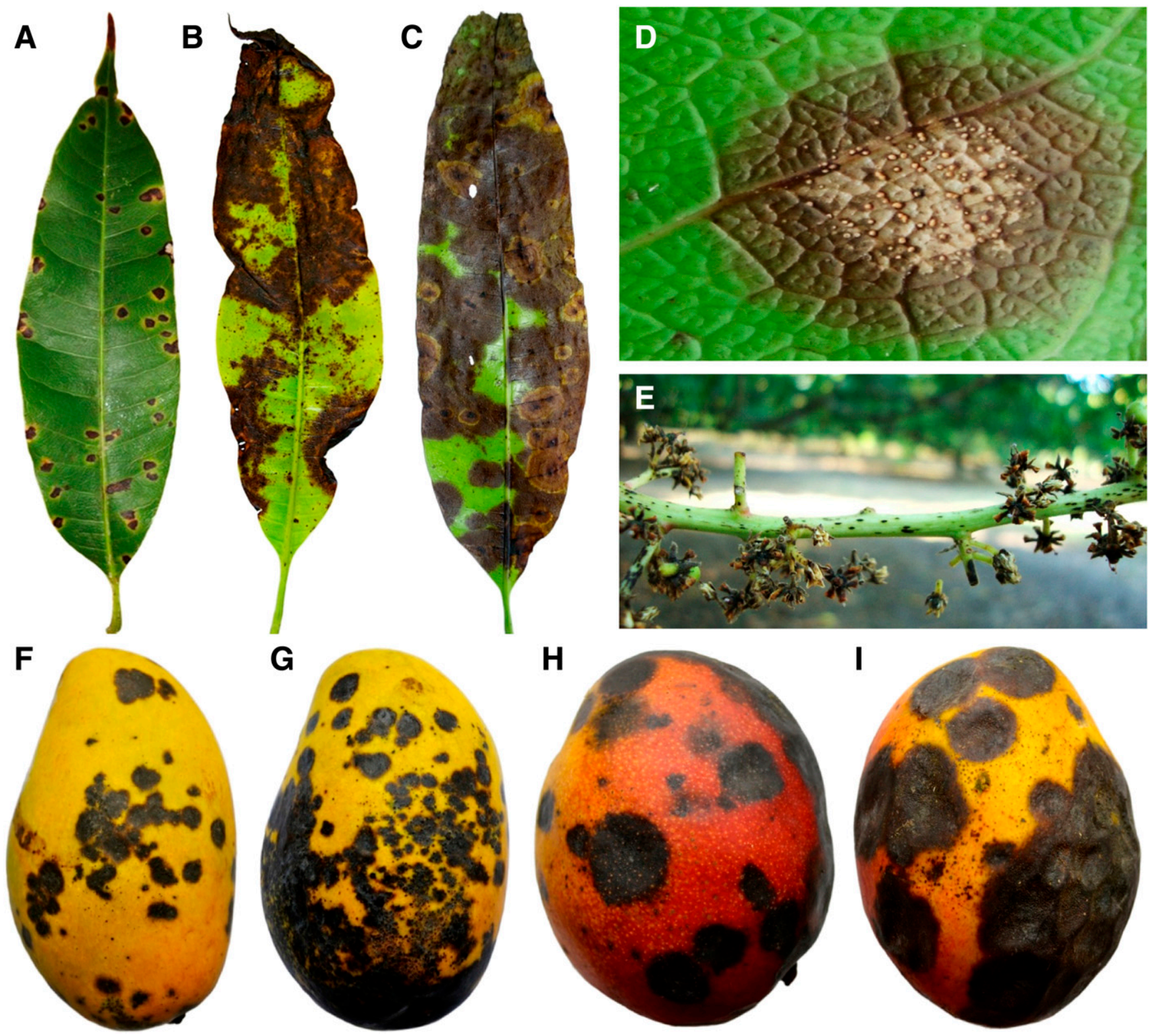

Fig. 1. Anthracnose symptoms caused by Colletotrichum spp. on mango tissues of the following cultivars: $\mathbf{A}$, Tommy Atkins; $\mathbf{B}$, C, D, and E, Ataulfo; $\mathbf{F}$ and $\mathbf{G}$, Manila; and $\mathbf{H}$ and I, Haden. A, Irregular necrotic lesions on leaves. B and C, Leaf blight. D, Acervuli on a necrotic foliar lesion. E, Blight of panicles. F, G, H, and I, Fruits showing irregular and sunken necrotic lesions. 
Although $C$. siamense was found in all mango growing states, no preference of this species with a specific tissue, cultivar, or collection site was observed, because it was obtained specifically from mango leaves and fruits as well as from various cultivars (Ataulfo, Manililla, Haden, Kent, Keitt, Manila, and Tommy Atkins) and collection sites of the main producing states of Mexico. Furthermore, it was not possible to relate their specificity to tissues and mango cultivars because of the low number of isolates analyzed.

Pathogenicity and virulence on fruits. All Colletotrichum isolates were pathogenic to mango fruits. Inoculated fruits developed sunken necrotic lesions on pericarp, whereas control fruits remained disease free. Fungal colonies were reisolated from all symptomatic fruits and were found to be morphologically identical to the original isolates inoculated on mango fruits, thus fulfilling Koch's postulates.
There were significant differences $(P \leq 0.05)$ in lesion diameter produced by the different Colletotrichum species tested in this study. $C$. siamense and $C$. asianum were the most virulent species, with a mean lesion diameter of 17.4 and $16.9 \mathrm{~mm}$, respectively. C. tropicale exhibited intermediate virulence, with a mean lesion diameter of $13.9 \mathrm{~mm}$, whereas $C$. fructicola and $C$. alienum were significantly less virulent than all other species (Fig. 5).

\section{Discussion}

Our phylogenetic analysis using the ApMat marker revealed that $C$. alienum, $C$. asianum, $C$. fructicola, $C$. siamense, and $C$. tropicale were associated with symptoms of mango anthracnose. Thus, this study represents the first report of $C$. siamense, $C$. tropicale, $C$. alienum, and C. fructicola associated with mango in Mexico. Previous studies recommend the use of the ApMat marker for

Table 1. Colletotrichum isolates included in the analysis of ApMat sequence data, along with information on the taxon, host, geographic location, and GenBank accession number

\begin{tabular}{|c|c|c|c|c|}
\hline Taxon & Isolate code co $^{\mathrm{z}}$ & Host & Geographic location & GenBank accession no. \\
\hline C. aenigma & ICMP18608 & Persea americana & Israel & KM360143 \\
\hline C. aeschynomenes & ICMP17673 & Aeschynomene virginica & United States & KM360145 \\
\hline \multirow[t]{4}{*}{ C. alienum } & ICMP12071 & Malus domestica & New Zealand & KC888927 \\
\hline & LF322 & Camellia sinensis & China & KJ954545 \\
\hline & UACH376 & Mangifera indica & Mexico & MK016305 \\
\hline & UACH360 & Mangifera indica & Mexico & MK016306 \\
\hline \multirow[t]{23}{*}{ C. asianum } & CBS130418 & Coffea arabica & Thailand & FR718814 \\
\hline & LC0037 & Coffee berry & Thailand & JQ899285 \\
\hline & LC0038 & Coffee berry & Thailand & JQ899286 \\
\hline & MTCC11680, GM595 & Mangifera indica & India & JQ894554 \\
\hline & UACH307 & Mangifera indica & Mexico & MK016307 \\
\hline & UACH348 & Mangifera indica & Mexico & MK016308 \\
\hline & UACH318 & Mangifera indica & Mexico & MK016309 \\
\hline & UACH337 & Mangifera indica & Mexico & MK016310 \\
\hline & UACH305 & Mangifera indica & Mexico & MK016311 \\
\hline & UACH341 & Mangifera indica & Mexico & MK016312 \\
\hline & $\mathrm{UACH} 323$ & Mangifera indica & Mexico & MK016313 \\
\hline & UACH310 & Mangifera indica & Mexico & MK016314 \\
\hline & UACH299 & Mangifera indica & Mexico & MK016315 \\
\hline & UACH311 & Mangifera indica & Mexico & MK016316 \\
\hline & UACH295 & Mangifera indica & Mexico & MK016317 \\
\hline & $\mathrm{UACH} 340$ & Mangifera indica & Mexico & MK016318 \\
\hline & UACH335 & Mangifera indica & Mexico & MK016319 \\
\hline & UACH308 & Mangifera indica & Mexico & MK016320 \\
\hline & UACH338 & Mangifera indica & Mexico & MK016321 \\
\hline & UACH336 & Mangifera indica & Mexico & MK016322 \\
\hline & $\mathrm{UACH} 312$ & Mangifera indica & Mexico & MK016323 \\
\hline & UACH339 & Mangifera indica & Mexico & MK016324 \\
\hline & $\mathrm{UACH} 315$ & Mangifera indica & Mexico & MK016325 \\
\hline C. chrysophilum & URM7362 & Musa sp. & Brazil & KX094325 \\
\hline C. chrysophilum & CMM4292 & Musa sp. & Brazil & KX094324 \\
\hline C. conoides & MYL24 & Actinidia chinensis & China & MG198007 \\
\hline C. endophyticum & YN1A4 & Camellia sinensis & China & KU251734 \\
\hline C. fructicola & CBS130416 & Coffea arabica & Thailand & JQ899290 \\
\hline C. fructicola & Coll996 & Rhexia virginica & United States & JX145324 \\
\hline C. fructicola & CollP1 & Vaccinium corymbosum & United States & JX145316 \\
\hline C. fructicola & UACH298 & Mangifera indica & Mexico & MK016326 \\
\hline C. gloeosporioides & CBS112999 & Citrus sinensis & Italy & JQ807843 \\
\hline C. hebeiense & JZB330024, SD4S2 & Vitis vinifera & China & KF377573 \\
\hline C. hebeiense & JZB330028, K3 & Vitis vinifera & China & KF377562 \\
\hline C. horii & ICMP10492 & Diospyros kaki & Japan & JQ807840 \\
\hline C. musae & CBS116870 & Musa sp. & United States & KC888926 \\
\hline C. musae & CMM4423 & Musa sp. & Brazil & KX094328 \\
\hline C. nupharicola & $\mathrm{OAC1}$ & Areca catechu & India & KU239773 \\
\hline
\end{tabular}

(Continued on next page)

${ }^{\mathrm{z}}$ Type isolates are shown in bold. ICMP = International Collection of Microorganisms From Plants, Landcare Research, Auckland, New Zealand; LF = Working collection of Fang Liu, housed at the Chinese Academy of Sciences (CAS), China; UACH = Culture Collection of Phytopathogenic Fungi of Department of Agricultural Parasitology, Chapingo Autonomous University, Mexico; CBS = Centraalbureau voor Schimmelcultures, Utrecht, Netherlands; LC = Working collection of Lei Cai, housed at CAS, China; MTCC = Microbial Type Culture Collection and Gene Bank, Chandigarh, India; URM = Culture collection "University Recife Mycologia," Recife, Brazil; and CMM = Culture Collection of Phytopathogenic Fungi "Professora Maria Menezes," Universidade Federal Rural de Pernambuco, Recife, Brazil. 
accurate identification of $C$. siamense (Sharma et al. 2015, 2017) and for delimitation of cryptic species within the $C$. gloeosporioides species complex (Doyle et al. 2013; Pardo-De la Hoz et al. 2016; Rojas et al. 2010; Sharma et al. 2013, 2017; Silva et al. 2012; Vieira et al. 2014). In addition, Liu et al. (2015) demonstrated that 22 Colletotrichum species, including $C$. alienum, $C$. asianum, $C$. fructicola, $C$. siamense, and $C$. tropicale, were clearly delimitated with the ApMat marker; however, other species in the $C$. gloeosporioides species complex such as $C$. jiangxiense Liu \& Cai and C. kahawae Waller $\&$ Bridge cannot be distinguished from each other by the ApMat marker and their identification requires a phylogenetic analysis using ApMat and glutamine synthetase concatenated alignments.

Pathogenicity tests performed with isolates of $C$. siamense, C. asianum, C. tropicale, C. alienum, and C. fructicola confirmed that these species are responsible for causing mango anthracnose in Mexico. Furthermore, the present findings showed that
C. gloeosporioides sensu stricto is not a common pathogen of mango fruits in Mexico and demonstrated that at least five Colletotrichum species causing mango anthracnose can be found, as reported for Brazil (Lima et al. 2013), India (Sharma et al. 2013), Australia (Shivas et al. 2016), and Colombia (Pardo-De la Hoz et al. 2016).

$C$. siamense was the most frequently isolated species from mango tissues with anthracnose symptoms in Mexico. This fungal species has been previously associated with mango tissues in Brazil (Lima et al. 2013; Vieira et al. 2014), India (Sharma et al. 2013, 2015), Colombia (Pardo-De la Hoz et al. 2016), China (Mo et al. 2018), and Australia (Giblin et al. 2018). In our study, C. siamense showed a similar virulence as $C$. asianum producing the larger lesions on mango fruit, in contrast to the study by Lima et al. (2013), who determined $C$. asianum as a species more virulent than $C$. siamense (syn. $C$. dianesei) in Brazil.

C. asianum was the second most prevalent species found in symptomatic tissues from mango in this study. Similarly, Lima et al.

Table 1. (Continued from previous page)

\begin{tabular}{|c|c|c|c|c|}
\hline Taxon & Isolate $\operatorname{code}^{\mathrm{z}}$ & Host & Geographic location & GenBank accession no. \\
\hline C. nupharicola & CBS470.96 & Nuphar lutea & United States & JX145319 \\
\hline C. nupharicola & CBS472.96 & Nymphaea odorata & United States & JX145320 \\
\hline C. perseae & GA100 & P. americana & Israel & KX620177 \\
\hline C. queenslandicum & ICMP1778 & Carica papaya & Australia & KC888928 \\
\hline C. salsolae & ICMP19051 & Salsola tragus & Hungary & KC888925 \\
\hline \multirow[t]{35}{*}{ C. siamense } & CBS130417 & Coffea arabica & Thailand & JQ899289 \\
\hline & GN1 & Azadirachta indica & India & KC790673 \\
\hline & UACH345 & Mangifera indica & Mexico & MK016327 \\
\hline & UACH302 & Mangifera indica & Mexico & MK016328 \\
\hline & UACH320 & Mangifera indica & Mexico & MK016329 \\
\hline & UACH321 & Mangifera indica & Mexico & MK016330 \\
\hline & UACH325 & Mangifera indica & Mexico & MK016331 \\
\hline & UACH326 & Mangifera indica & Mexico & MK016332 \\
\hline & UACH324 & Mangifera indica & Mexico & MK016333 \\
\hline & UACH301 & Mangifera indica & Mexico & MK016334 \\
\hline & UACH350 & Mangifera indica & Mexico & MK016335 \\
\hline & UACH316 & Mangifera indica & Mexico & MK016336 \\
\hline & UACH330 & Mangifera indica & Mexico & MK016337 \\
\hline & UACH314 & Mangifera indica & Mexico & MK016338 \\
\hline & UACH331 & Mangifera indica & Mexico & MK016339 \\
\hline & UACH329 & Mangifera indica & Mexico & MK016340 \\
\hline & UACH333 & Mangifera indica & Mexico & MK016341 \\
\hline & UACH334 & Mangifera indica & Mexico & MK016342 \\
\hline & UACH294 & Mangifera indica & Mexico & MK016343 \\
\hline & UACH309 & Mangifera indica & Mexico & MK016344 \\
\hline & UACH328 & Mangifera indica & Mexico & MK016345 \\
\hline & UACH313 & Mangifera indica & Mexico & MK016346 \\
\hline & UACH346 & Mangifera indica & Mexico & MK016347 \\
\hline & UACH349 & Mangifera indica & Mexico & MK016348 \\
\hline & $\mathrm{UACH} 322$ & Mangifera indica & Mexico & MK016349 \\
\hline & $\mathrm{UACH} 342$ & Mangifera indica & Mexico & MK016350 \\
\hline & UACH351 & Mangifera indica & Mexico & MK016351 \\
\hline & UACH317 & Mangifera indica & Mexico & MK016352 \\
\hline & UACH296 & Mangifera indica & Mexico & MK016353 \\
\hline & UACH327 & Mangifera indica & Mexico & MK016354 \\
\hline & UACH303 & Mangifera indica & Mexico & MK016355 \\
\hline & UACH332 & Mangifera indica & Mexico & MK016356 \\
\hline & UACH343 & Mangifera indica & Mexico & MK016357 \\
\hline & UACH319 & Mangifera indica & Mexico & MK016358 \\
\hline & UACH304 & Mangifera indica & Mexico & MK016359 \\
\hline \multirow{7}{*}{ C. tropicale } & CBS124949 & Theobroma cacao & Panama & GU994425 \\
\hline & CMM3780 & Mangifera indica & Brazil & KJ155467 \\
\hline & Coll918 & Terpsichore taxifolia & Puerto Rico & JX145307 \\
\hline & UACH297 & Mangifera indica & Mexico & MK016360 \\
\hline & UACH300 & Mangifera indica & Mexico & MK016362 \\
\hline & UACH306 & Mangifera indica & Mexico & MK016361 \\
\hline & UACH347 & Mangifera indica & Mexico & MK016363 \\
\hline \multirow[t]{2}{*}{ C. theobromicola } & GJS0843, CBS124944 & Theobroma cacao & Panama & GU994447 \\
\hline & GJS0850, CBS124945 & Theobroma cacao & Panama & GU994448 \\
\hline
\end{tabular}


(2013) and Vieira et al. (2014) recorded that $C$. asianum was the second most frequently isolated species from mango tissues in Brazil. In addition, this species has been associated with mango anthracnose in Australia (Giblin et al. 2018; James et al. 2014; Shivas et al. 2016; Weir et al. 2012), Philippines, Panama (Weir et al. 2012), Thailand (Phoulivong et al. 2010; Weir et al. 2012), India (Sharma et al. 2013), Ghana (Honger et al. 2014), Colombia (Pardo-De la Hoz et al. 2016), and China (Mo et al. 2018), enlisting this Colletotrichum species as the most widely distributed in major mango producing countries. In our pathogenicity tests, isolates of $C$. asianum showed high virulence, which is in agreement with the results reported by Sharma et al. (2013) and Vieira et al. (2014) for Colletotrichum isolates obtained from mango from India and Brazil, respectively.

C. tropicale was the third most common species of all of the isolates identified in our study. This is in line with the studies published by Lima et al. (2013) and Vieira et al. (2014), who reported a lower
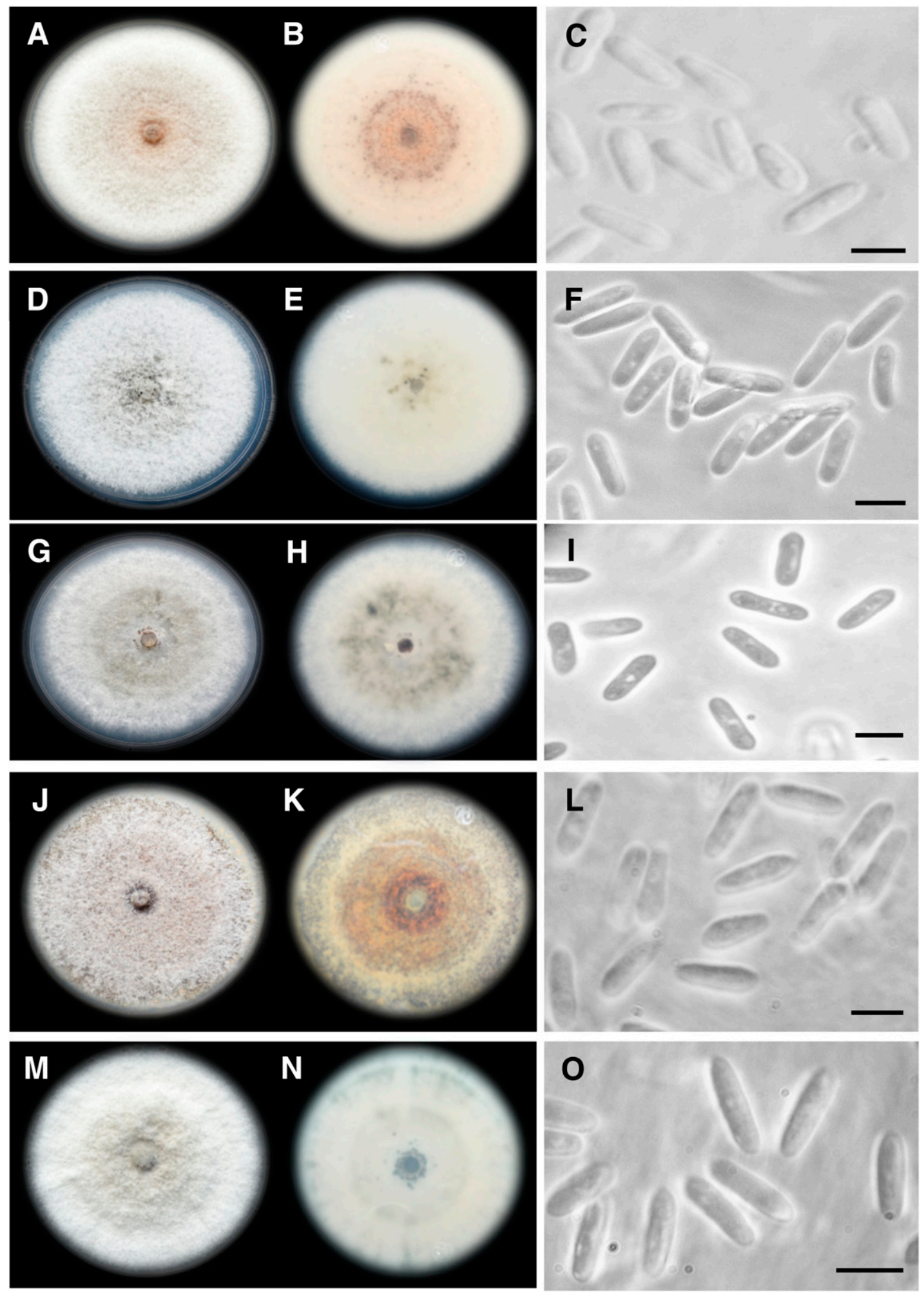

Fig. 2. Colony morphology and conidia of five Colletotrichum species after 9 days of incubation at $25^{\circ} \mathrm{C}$ under continuous dark (left, upper view of colony; center, reverse view of colony; and right, conidia). A, B, and C, Colletotrichum siamense. D, E, and F, C. asianum. G, H, and I, C. tropicale. J, K, and L, C. fructicola. M, N, and O, C. alienum. Scale bars $=10 \mu \mathrm{m}$. 
prevalence of C. tropicale with respect to C. siamense (syn. C. dianesei) and C. asianum in mango tissues from Brazil. Pathogenicity tests showed that $C$. tropicale was more virulent than $C$. fructicola, which is in agreement with the results reported by Lima et al.
(2013) and Vieira et al. (2014), with isolates obtained from symptomatic and asymptomatic mango tissues, respectively.

C. alienum was represented by two isolates in this study. This fungus has been previously associated with several hosts, including fruit

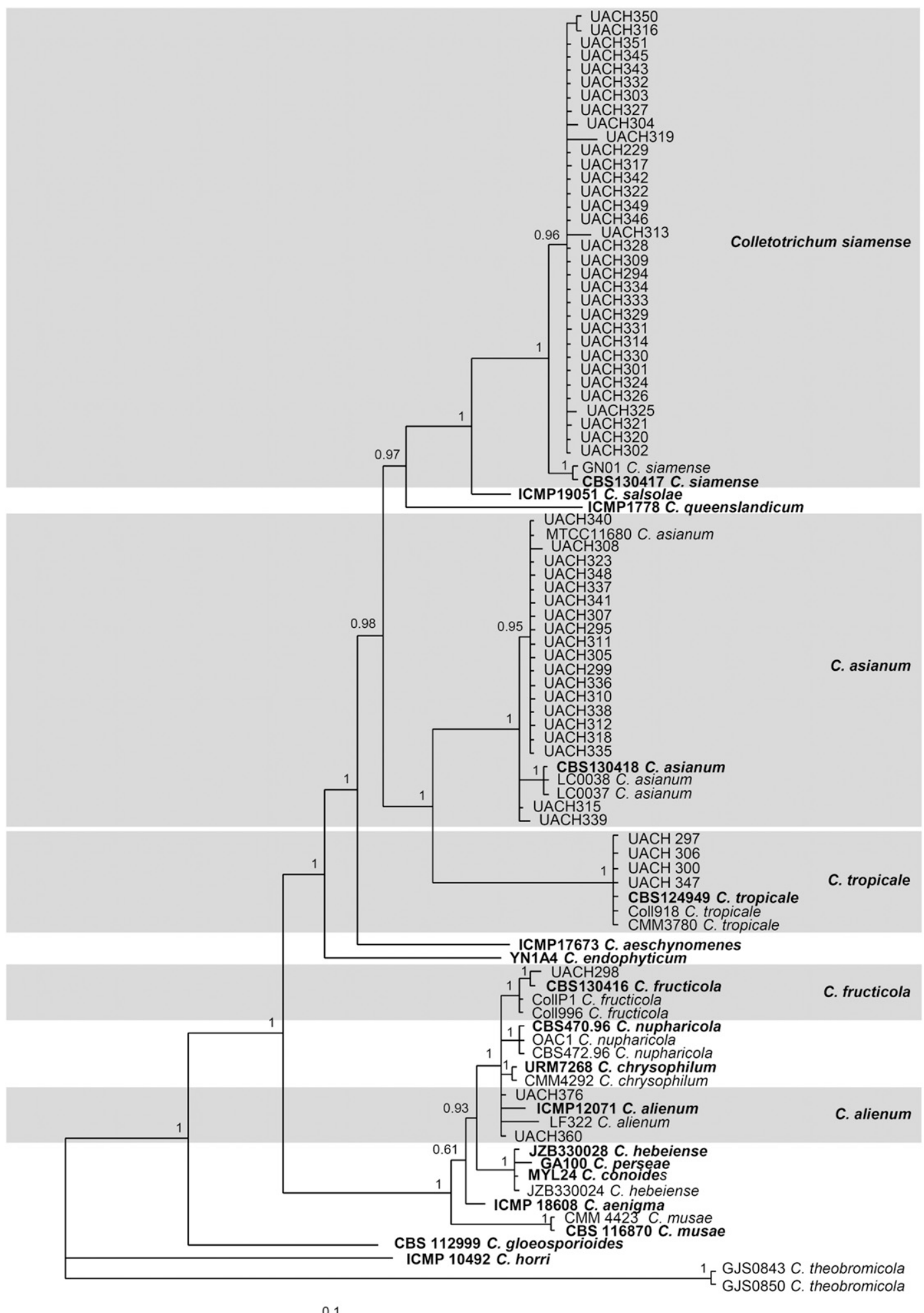

Fig. 3. Phylogenetic tree constructed based on Bayesian inference of sequence data of the Apn2/MAT intergenic spacer from 93 Colletotrichum isolates. The tree shows the phylogenetic relationships of Colletotrichum species isolated from Mangifera indica and selected Colletotrichum species. Bayesian posterior probability values $\geq 0.5$ are shown in each node. Ex-type or ex-epitype sequences are emphasized in bold. Culture accession numbers are listed. C. theobromicola is used as outgroup. The scale bar indicates the number of expected changes per site. UACH = Culture Collection of Phytopathogenic Fungi of Department of Agricultural Parasitology, Chapingo Autonomous University, Mexico; CBS = Centraalbureau voor Schimmelcultures, Utrecht, Netherlands; ICMP = International Collection of Microorganisms From Plants, Landcare Research, Auckland, New Zealand; MTCC = Microbial Type Culture Collection and Gene Bank, Chandigarh, India; LC = Working collection of Lei Cai, housed at the Chinese Academy of Sciences (CAS), China; CMM = Culture Collection of Phytopathogenic Fungi "Professora Maria Menezes," Universidade Federal Rural de Pernambuco, Recife, Brazil; URM = Culture collection "University Recife Mycologia," Recife, Brazil; and LF = Working collection of Fang Liu, housed at CAS, China. 
crops such as strawberry (Fragaria $\times$ ananassa), avocado (Persea americana), and apple (Malus domestica) (Farr and Rossman 2019). However, this study represents the first report worldwide of this fungal species causing mango anthracnose.

C. fructicola was represented only by one isolate in this study. This species was previously reported to cause mango anthracnose in Brazil (Lima et al. 2013), India (Sharma et al. 2013), Korea (Jao et al. 2016), and China (Mo et al. 2018). However, Vieira et al. (2014) referred to $C$. fructicola as an endophytic fungus of mango

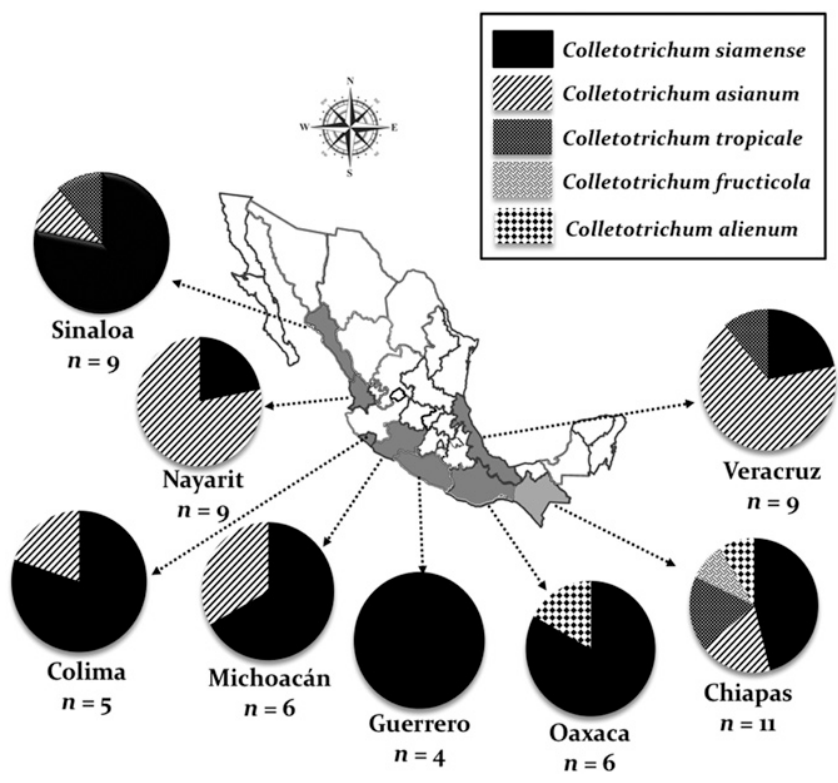

Fig. 4. Collection sites of Colletotrichum isolates associated with mango anthracnose in eight states from Mexico. Circles represent the association frequency of each species with plants exhibiting symptoms of anthracnose in each site sampled. $n$ is the number of isolates analyzed in each mango growing state. tissues in northeastern Brazil. This species has also been identified on apple and avocado fruits in Japan (Yokosawa et al. 2017) and Israel (Sharma et al. 2017), respectively. In addition, FuentesAragón et al. (2018) identified this fungal species as the causal agent of anthracnose and soft rot in avocado fruits in Mexico. Results of pathogenicity tests in our study revealed that the isolate of C. fructicola caused the smallest lesions on mango fruits, which is in agreement with the findings of Sharma et al. (2013) and Vieira et al. (2014), who reported that this fungal species was the least virulent of Colletotrichum isolates inoculated on mango fruits in India and Brazil, respectively.

In the current study, the virulence assessment of the isolates of five Colletotrichum species causing mango anthracnose in Mexico was estimated. However, these results may not reflect the true virulence potential of these species because the symptoms developed in mango fruits can vary greatly, according to various factors such as the fruit type, fruit condition, humidity, temperature, inoculum concentration, and inoculation method (Freeman et al. 1998; Giblin et al. 2010; Sanders and Korsten 2003). For this reason, further research is suggested to estimate the potential virulence of Colletotrichum species in a natural infection experiment instead of by artificially generated infections, as mentioned by Prihastuti et al. (2009), Lima et al. (2013), and Vieira et al. (2014). It is also necessary to evaluate the response of the major mango cultivars produced in Mexico to the infection by Colletotrichum spp., in order to identify the levels of resistance and tolerance of those cultivars to this disease.

Overall, this study represents the most detailed research of $\mathrm{Col}$ letotrichum species associated with mango anthracnose in Mexico and the findings have comprehensive relevance in various aspects of the disease, since accurate identification of closely related $\mathrm{Col}$ letotrichum species is important to determine the geographical distribution of a particular fungal species and to formulate quarantine regulations, as well as to understand the epidemiology and to establish strategies for the integrated management of diseases in mango orchards. In addition, further studies are needed to determine the fungicide sensitivity of Colletotrichum isolates from mango in Mexico.

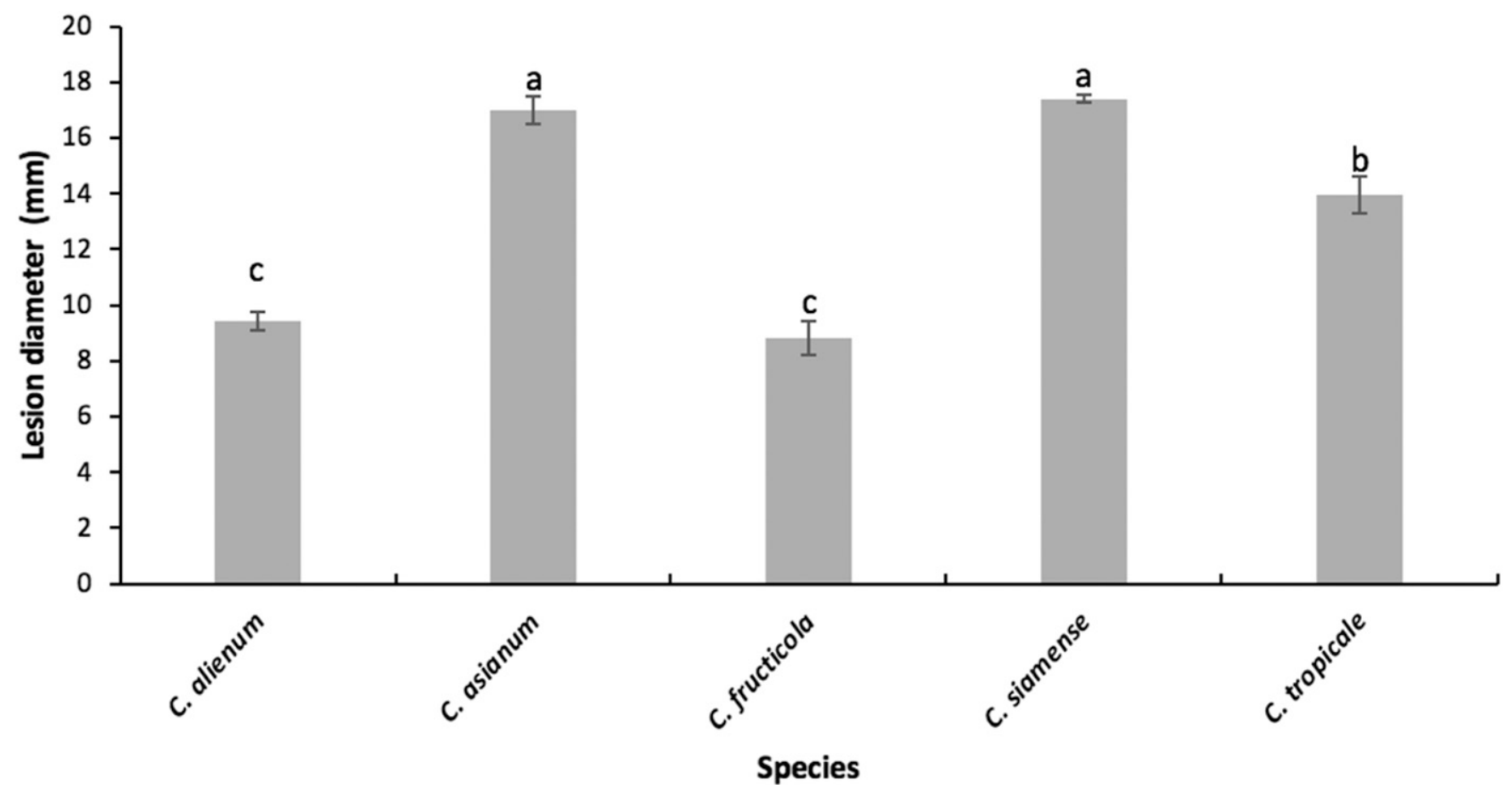

Fig. 5. Mean lesion diameter (in millimeters) caused by five Colletotrichum species associated with mango anthracnose in Mexico, 5 days after inoculation with mycelium colonized agar plugs onto wounded fruits of Manila cultivar. Bars above columns are the standard error of the mean. Columns with the same letter do not differ significantly according to Fisher's least significant difference test $(P \leq 0.05)$. 


\section{Acknowledgments}

We thank Eréndira Guadalupe Ríos López and Teresa Berenice Uribe Cortes for technical assistance in the laboratory work. We also thank Dr. Rients Niks for critical reading of the manuscript.

\section{Literature Cited}

Arauz, L. F. 2000. Mango anthracnose: Economic impact and current options for integrated management. Plant Dis. 84:600-611.

Cai, L., Hyde, K. D., Taylor, P. W. J., Weir, B. S., Waller, J., Abang, M. M., Zhang, J. Z., Yang, Y. L., Phoulivong, S., Liu, Z. Y., Prihastuti, H., Shivas, R. G., McKenzie, E. H. C., and Johnston, P. R. 2009. A polyphasic approach for studying Colletotrichum. Fungal Divers. 39:183-204.

Cannon, P. F., Damm, U., Johnston, P. R., and Weir, B. S. 2012. Colletotrichum Current status and future directions. Stud. Mycol. 73:181-213.

Damm, U., Cannon, P. F., Woudenberg, J. H. C., and Crous, P. W. 2012a. The Colletotrichum acutatum species complex. Stud. Mycol. 73:37-113.

Damm, U., Cannon, P. F., Woudenberg, J. H. C., Johnston, P. R., Weir, B. S., Tan, Y. P., Shivas, R. G., and Crous, P. W. 2012b. The Colletotrichum boninense species complex. Stud. Mycol. 73:1-36.

Damm, U., Sato, T., Alizadeh, A., Groenewald, J. Z., and Crous, P. W. 2019. The Colletotrichum dracaenophilum, C. magnum and C. orchidearum species complexes. Stud. Mycol. 92:1-46.

Doyle, J. J., and Doyle, J. L. 1990. Isolation of plant DNA from fresh tissue. Focus 12:13-15.

Doyle, V. P., Oudemans, P. V., Rehner, S. A., and Litt, A. 2013. Habitat and host indicate lineage identity in Colletotrichum gloeosporioides $\mathrm{s}$. 1. from wild and agricultural landscapes in North America. PLoS One 8:e62394.

Farr, D. F., and Rossman, A. Y. 2019. Fungal Databases, U.S. National Fungus Collections. U.S. Department of Agriculture Agricultural Research Service. https://nt.ars-grin.gov/fungaldatabases/

Food and Agriculture Organization of the United Nations. 2017. FAOSTAT: Food and agriculture data. http://www.fao.org/faostat/en/\#home

Freeman, S., Katan, T., and Shabi, E. 1998. Characterization of Colletotrichum species responsible for anthracnose disease of various fruits. Plant Dis. 82: 596-605.

Fuentes-Aragón, D., Juárez-Vázquez, S. B., Vargas-Hernández, M., and SilvaRojas, H. V. 2018. Colletotrichum fructicola, a member of Colletotrichum gloeosporioides sensu lato, is the causal agent of anthracnose and soft rot in avocado fruits cv. "Hass." Mycobiology 46:92-100.

Giblin, F. R., Coates, L. M., and Irwin, J. A. G. 2010. Pathogenic diversity of avocado and mango isolates of Colletotrichum gloeosporioides causing anthracnose and pepper spot. Australas. Plant Pathol. 39:50-62.

Giblin, F. R., Tan, Y. P., Mitchell, R., Coates, L. M., Irwin, J. A. G., and Shivas, R. G. 2018. Colletotrichum species associated with pre-and post-harvest diseases of avocado and mango in eastern Australia. Australas. Plant Pathol. 47:269-276.

Goh, T. K. 1999. Single-spore isolation using a handmade glass needle. Fungal Divers. 2:47-63.

Gutiérrez-Alonso, J. G., Nieto-Ángel, D., Téliz-Ortiz, D., Zavaleta-Mejía, E., Vaquera-Huerta, H., Martínez-Damián, T., and Delgadillo-Sánchez, F. 2001. Características de crecimiento, germinación, esporulación y patogenicidad de aislamientos de Colletotrichum gloeosporioides Penz. obtenidos de frutos de mango (Mangifera indica L.). Rev. Mex. Fitopatol. 19:90-93.

Honger, J. O., Offei, S. K., Oduro, K. A., Odamtten, G. T., and Nyaku, S. T. 2014. Identification and species status of the mango biotype of Colletotrichum gloeosporioides in Ghana. Eur. J. Plant Pathol. 140:455-467.

Hyde, K. D., Cai, L., Cannon, P. F., Crouch, J. A., Crous, P. W., Damm, U., Goodwin, P. H., Chen, H., Johnston, P. R., Jones, E. B. G., Liu, Z. Y., McKenzie, E. H. C., Moriwaki, J., Noireung, P., Pennycook, S. R., Pfenning, L. H., Prihastuti, H., Sato, T., Shivas, R. G., Tan, Y. P., Taylor, P. W. J., Weir, B. S., Yang, Y. L., and Zhang, J. Z. 2009a. Colletotrichum-names in current use. Fungal Divers. 39:147-182.

Hyde, K. D., Cai, L., McKenzie, E. H. C., Yang, Y. L., Zhang, J. Z., and Prihastuti, H. 2009b. Colletotrichum: A catalogue of confusion. Fungal Divers. 39:1-17.

James, R. S., Ray, J., Tan, Y. P., and Shivas, R. G. 2014. Colletotrichum siamense, C. theobromicola and C. queenslandicum from several plant species and the identification of $C$. asianum in the Northern Territory, Australia. Australas. Plant Dis. Notes 9:138.

Jao, J. H., Lim, C. K., Choi, I. Y., Park, M. J., and Shin, H. D. 2016. First report of Colletotrichum fructicola causing anthracnose on mango in Korea. Plant Dis. 100:1793.

Jayawardena, R. S., Hyde, K. D., Damm, U., Cai, L., Liu, M., Li, X. H., Zhang, W., Zhao, W. S., and Yan, J. Y. 2016. Notes on currently accepted species of Colletotrichum. Mycosphere 7:1192-1260.

Kumar, S., Stecher, G., and Tamura, K. 2016. MEGA7: Molecular Evolutionary Genetics Analysis version 7.0 for bigger datasets. Mol. Biol. Evol. 33: 1870-1874.

Lima, N. B., de A. Batista, M. V., Morais, M. A., Jr., Barbosa, M. A. G., Michereff, S. J., Hyde, K. D., and Câmara, M. P. S. 2013. Five Colletotrichum species are responsible for mango anthracnose in northeastern Brazil. Fungal Divers. 61: 75-88.
Liu, F., Weir, B. S., Damm, U., Crous, P. W., Wang, Y., Liu, B., Wang, M., Zhang, M., and Cai, L. 2015. Unravelling Colletotrichum species associated with Camellia: Employing ApMat and GS loci to resolve species in the $C$. gloeosporioides complex. Persoonia 35:63-86.

Manzano León, A. M., Serra-Hernández, W., García-Pérez, L., Crespo, K., and Guarnaccia, V. 2018. First report of leaf anthracnose caused by Colletotrichum grossum on mango (Mangifera indica) in Cuba. J. Plant Pathol. 100:329.

Marin-Felix, Y., Groenewald, J. Z., Cai, L., Chen, Q., Marincowitz, S., Barnes, I., Bensch, K., Braun, U., Camporesi, E., Damm, U., de Beer, Z. W., Dissanayake, A., Edwards, J., Giraldo, A., Hernandez-Restrepo, M., Hyde, K. D., Jayawardena, R. S., Lombard, L., Luangsa-ard, J., McTaggart, A. R., Rossman, A. Y., Sandoval-Denis, M., Shen, M., Shivas, R. G., Tan, Y. P., van der Linde, E. J., Wingfield, M. J., Wood, A. R., Zhang, J. Q., Zhang, Y., and Crous, P. W. 2017. Genera of phytopathogenic fungi: GOPHY 1. Stud. Mycol. 86:99-216.

Mo, J., Zhao, G., Li, Q., Soalngi, G. S., Tang, L., Huang, S., Guo, T., and Hsiang, T. 2018. Identification and characterization of Colletotrichum species associated with mango anthracnose in Guangxi, China. Plant Dis. 102: 1283-1289.

Mukherjee, S. K., and Litz, R. E. 2009. Introduction: Botany and importance. Pages 1-18 in: The Mango: Botany, Production and Uses. R. E. Litz, ed. CABI Publishing, London, UK.

Nylander, J. A. A. 2004. MrModeltest v2. Program distributed by the author Evolutionary Biology Centre, Uppsala University, Uppsala, Sweden.

Page, R. D. M. 1996. TreeView: An application to display phylogenetic trees on personal computers. Comput. Appl. Biosci. 12:357-358.

Pardo-De la Hoz, C. J., Calderon, C., Rincon, A. M., Cardenas, M., Danies, G., Lopez-Kleine, L., Restrepo, S., and Jimenez, P. 2016. Species from the Colletotrichum acutatum, Colletotrichum boninense and Colletotrichum gloeosporioides species complexes associated with tree tomato and mango crops in Colombia. Plant Pathol. 65:227-237.

Paull, R. E., and Duarte, O. 2011. Tropical Fruits, Vol. 1, 2nd ed. CABI Publishing, London, UK

Phoulivong, S., Cai, L., Chen, H., McKenzie, E. H. C., Abdelsalam, K., Chukeatirote, E., and Hyde, K. D. 2010. Colletotrichum gloeosporioides is not a common pathogen on tropical fruits. Fungal Divers. 44:33-43.

Ploetz, R. C. 2003. Diseases of mango. Pages 327-363 in: Diseases of Tropical Fruit Crops. R. C. Ploetz, ed. CABI Publishing, London, UK

Ploetz, R. C., and Freeman, S. 2009. Foliar, floral, and soilborne diseases. Pages 231-302 in: The Mango: Botany, Production and Uses. R. E. Litz, ed. CABI Publishing, London, UK.

Prakash, O. 2004. Diseases and disorders of mango and their management. Pages 511-619 in: Diseases of Fruits and Vegetables, Vol. 1. S. A. M. H. Naqvi, ed. Kluwer Academic Publishers, Dordrecht, Netherlands.

Prihastuti, H., Cai, L., Chen, H., McKenzie, E. H. C., and Hyde, K. D. 2009. Characterization of Colletotrichum species associated with coffee berries in northern Thailand. Fungal Divers. 39:89-109.

Prusky, D., Kobiler, I., Miyara, I., and Alkan, N. 2009. Fruit diseases. Pages 210-230 in: The Mango: Botany, Production and Uses. R. E. Litz, ed. CABI Publishing, London, UK.

Qin, L. P., Yu, G. M., Zhang, Y., Su, Q., Chen, Y. L., Nong, Q., Huang, S. L., and Xie, L. 2019. First report of anthracnose of Mangifera indica caused by Colletotrichum scovillei in China. Plant Dis. 103:1043.

Rojas, E. I., Rehner, S. A., Samuels, G. J., Van Bael, S. A., Herre, E. A., Cannon, P., Chen, R., Pang, J., Wang, R., Zhang, Y., Peng, Y. Q., and Sha, T. 2010. Colletotrichum gloeosporioides s. 1. associated with Theobroma cacao and other plants in Panamá: Multilocus phylogenies distinguish hostassociated pathogens from asymptomatic endophytes. Mycologia 102:13181338.

Rojas-Martínez, R. I., Zavaleta-Mejía, E., Nieto-Ángel, D., and Acosta-Ramos, M. 2008. Virulence and genetic variation of isolates of Colletotrichum gloeosporioides (Penz.) Penz. and Sacc. on mango (Mangifera indica L.) cv. Haden. Rev. Mex. Fitopatol. 26:21-26.

Ronquist, F., Teslenko, M., Van der Mark, P., Ayres, D. L., Darling, A., Höhna, S., Larget, B., Liu, L., Suchard, M. A., and Huelsenbeck, J. P. 2012. MrBayes v. 3.2: Efficient Bayesian phylogenetic inference and model choice across a large model space. Syst. Biol. 61:539-542.

Sanders, G. M., and Korsten, L. 2003. Comparison of cross inoculation potential of South African avocado and mango isolates of Colletotrichum gloeosporioides. Microbiol. Res. 158:143-150.

Servicio de Informacion Agroalimentaria y Pesquera. 2017. Servicio de Informacion Agroalimentaria y Pesquera (SIAP). https://www.gob.mx/siap

Sharma, G., Kumar, N., and Shenoy, B. D. 2015. Resolving the Colletotrichum siamense species complex using ApMat marker. Fungal Divers. 71: 247-264.

Sharma, G., Kumar, N., Weir, B. S., Hyde, K. D., and Shenoy, B. D. 2013. The ApMat marker can resolve Colletotrichum species: A case study with Mangifera indica. Fungal Divers. 61:117-138.

Sharma, G., Maymon, M., and Freeman, S. 2017. Epidemiology, pathology and identification of Colletotrichum including a novel species associated with avocado (Persea americana) anthracnose in Israel. Sci. Rep. $7: 15839$ 
Shivas, R. G., Tan, Y. P., Edwards, J., Dinh, Q., Maxwell, A., Andjic, V., Liberato, J. R., Anderson, C., Beasley, D. R., Bransgrove, K., Coates, L. M., Cowan, K., Daniel, R., Dean, J. R., Lomavatu, M. F., Mercado-Escueta, D., Mitchell, R. W., Thangavel, R., Tran-Nguyen, L. T. T., and Weir, B. S. 2016. Colletotrichum species in Australia. Australas. Plant Pathol. 45:447-464.

Silva, N. D., Talhinhas, P., Várzea, V., Cai, L., Paulo, O. S., and Batista, D. 2012. Application of the Apn2/MAT locus to improve the systematics of the Colletotrichum gloeosporioides complex: An example from coffee (Coffea spp.) host. Mycologia 104:396-409.

Staden, R., Beal, K. F., and Bonfield, J. K. 1998. The Staden package, 1998. Pages 115-130 in: Bioinformatics Methods and Protocols. S. Misener and S. A. Krawetz, eds. Humana, New York.
Udayanga, D., Manamgoda, D. S., Liu, X., Chukeatirote, E., and Hyde, K. D. 2013. What are the common anthracnose pathogens of tropical fruits? Fungal Divers. 61:165-179.

Vieira, W. A. S., Michereff, S. J., de Morais, M. A., Jr., Hyde, K. D., and Câmara, M. P. S. 2014. Endophytic species of Colletotrichum associated with mango in northeastern Brazil. Fungal Divers. 67:181-202.

Weir, B. S., Johnston, P. R., and Damm, U. 2012. The Colletotrichum gloeosporioides species complex. Stud. Mycol. 73:115-180.

Yokosawa, S., Eguchi, N., Kondo, K., and Sato, T. 2017. Phylogenetic relationship and fungicide sensitivity of members of the Colletotrichum gloeosporioides species complex from apple. J. Gen. Plant Pathol. 83: 291-298. 